\title{
Uptake of Ruthenium-106 by Short-necked Clam
}

\author{
Ken-ichi KImURA and Ryushi ICHIKAwA* \\ (Received January 29, 1970)
}

In order to control the radioactive contamination of marine organisms due to the discharge of low level radioactive liquid wastes into the coastal sea, informations on the accumulation of radionuclide by marine organisms are strongly needed for the evaluation of the relationship between the level of the radionuclides in marine organisms and the rate of the discharge of wastes.

Ruthenium-106 is known to be one of the most abundant radionuclides to be released from the nuclear fuel reprocessing plant. Up to the present time, there were considerable number of reports concerning the uptake of ${ }^{106} \mathrm{Ru}$ by aquatic organisms from the environmental water. However, very little is known about the role of various environmental factors involved in the uptake of ${ }^{106} \mathrm{Ru}$ by marine organisms.

In the previous paper ${ }^{1)}$, the authors reported that the transfer of ${ }^{106} \mathrm{Ru}$ into coastal sea fish through aquatic food chain may be relatively small in comparison with the direct uptake from the surrounding sea water.

Jones $^{2)}$ observed that the absorption of nitrosyl ruthenium from sea water by a red algae, Porphyra lacinata, decreased as the $\mathrm{pH}$ of the medium fell, and that no significant difference in mode of uptake was found between the living and dead cells of a marine diatom, Phaeodactylum tricornutum.

Tsuruga $^{3}$ studied the effect of the chelating agent and co-existing elements on the uptake of ${ }^{106} \mathrm{Ru}$ by a red algae, Porphyra tenera, and found that these effects were comparatively small. Regarding carrier effect, Hiyama et al. ${ }^{4)}$ found by the tracer experiments using several kinds of marine organisms that the effect of stable ruthenium carrier added to the sea water was not clear with the exception for algae.

In recent studies carried out by Kečkeš et al., ${ }^{5,6)}$ they pointed out the greater importance of the physico-chemical form of ${ }^{106} \mathrm{Ru}$ on its uptake by a mussel, Mytilus galloprovincialis, and reported that the uptake of ${ }^{108} \mathrm{Ru}$ in chloride form was ten times higher than in nitrate form.

In a series of experiments on ${ }^{106} \mathrm{Ru}$ uptake by marine organisms, the present paper concerns the influence of some chemical and environmental factors, i.e., its chemical form, chelating agent, co-exising element and sandy mud on the uptake of ${ }^{106} \mathrm{Ru}$ by a marine bivalve in order to elucidate the uptake mechanism in more detail.

* Division of Environmental Health, National Institute of Radiological Sciences, Chiba, Japan. （木村健一。市川竜資：放射線医学総合研究所環境衙生研究部) 


\section{Materials and Methods}

The commercially available (The Radiochemical Center, Amersham) radioruthenium complex form was obtained for this experiment. The form was reported by the manufacturer to be Nitrosyl ruthenium nitrate complexes in nitric acid (RuNO-nitrato). In addition to this, nitro complex of nitrosylruthenium (RuNO-nitro), chloro complex of nitrosylruthenium (RuNO-chloro) and ruthenium chloride (Ru-chloro) were prepared to be applied for some cases of the present experiment series. These forms were derived from the above-mentioned original isotope solution by the method of Iwashima and Watari ${ }^{7}$ and contained less than $10^{-7} \mathrm{M}$ of carrier. It should be noted however that these chemical forms mentioned above indicate only the initial condition of the isotope solution before being added to the sea water. After being introduced in sea water, these are subject to the gradual change with time.

Short-necked clam, Tapes japonica, was used as the experimental material. They were purchased from a commercial source which was collected in Tokyo Bay. Prior to the experiment, they were acclimated to laboratory conditions.

In order to investigate the influence of the chemical form, and of existence of sandy mud as an environmental factor on the uptake of ${ }^{106} \mathrm{Ru}$, the clams ( $24 \mathrm{~g}$ in average weight) were placed in 14 liters of filtered sea water to which approximately 300 micro-curies of Ruthenium-106 in the form of either Ru-chloro or RuNO-nitro were added, and maintained for two weeks at room temperature $\left(20-26^{\circ} \mathrm{C}\right)$. In other vessels, they were placed in 3 kilo-grams of sandy mud through which radioactive sea water (approximately 500 micro-curies of ${ }^{106} \mathrm{Ru}$ in two forms as above in 14 liters of sea water) flowed continuously, and maintained for three weeks at the same temperature. This sandy mud with flowing sea water was contained in a plastic cage of small mesh which was kept in the vessel.

On the other hand, in experiments on the effect of co-existing element and chelating agent on the uptake of ${ }^{100} \mathrm{Ru}$, the clams ( $22 \mathrm{~g}$ in average weight) were placed in the sea water containing 420 micro-curies of Ruthenium-106 in RuNO-nitrato form in 19 liters to which various concentrations of Fe were added, and maintained for twelve days at room temperature $\left(20-25^{\circ} \mathrm{C}\right)$. In the case of EDTA, they were placed in the sea water containing 190 microcuries of Ruthenium-106 in RuNO-nitrato form in 15 liters to which various concentrations of EDTA were added, and maintained for five days at room temperature $\left(26-31^{\circ} \mathrm{C}\right)$. The concentrations of $\mathrm{Fe}$ and EDTA as its disodium salt added to the sea water were $0.1,1$, and $10 \mathrm{mg} /$ liter for each case.

In the uptake experiments, the clams were placed in the rearing sea water of each experimental vessel after the concentration of the radioactivity of the sea water reached approximately constant level. Each vessel was equipped with a filtration-aeration apparatus, through which the rearing water was forced to circulate continuously. 
At different intervals from the beginning of the experiment, three individuals were removed from each experimental vessel, washed in uncontaminated sea water and blotted lightly with filter paper. Then the clams were dissected into various organs, i.e., adductor muscle, foot, mantle, gill, visceral mass and shell. The determination of the radioactivity in individual sample was carried out by use of scintillation counter with a well type $\mathrm{NaI}$ crystal. In some cases, the activities of the soft part and shell were measured separately, using 'Armac' liquid scintillation detector.

The uptake of ${ }^{106} \mathrm{Ru}$ by the clam was expressed in terms of concentration factor (C. F.), i.e., the ratio of the nuclide content in organism to that in environmental water of the same weight.

\section{Results and Discussion}

The uptake of ${ }^{106} \mathrm{Ru}$ by the clam from sea water alone or from sea water with sandy mud over a period of 2-3 weeks is shown in Figs. 1-2. As shown in the figures, the uptake of ${ }^{106} \mathrm{Ru}$ by various organs of the clam reared under these two different environments
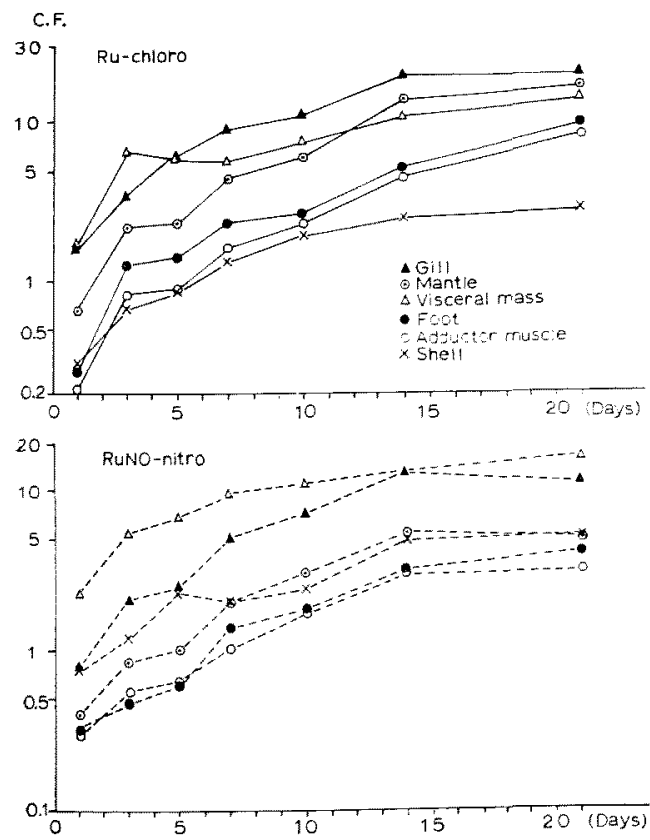

Fig. 1. Uptake of ${ }^{106} \mathrm{Ru}$ by short-necked clam, Tapes japonica, from sea water.

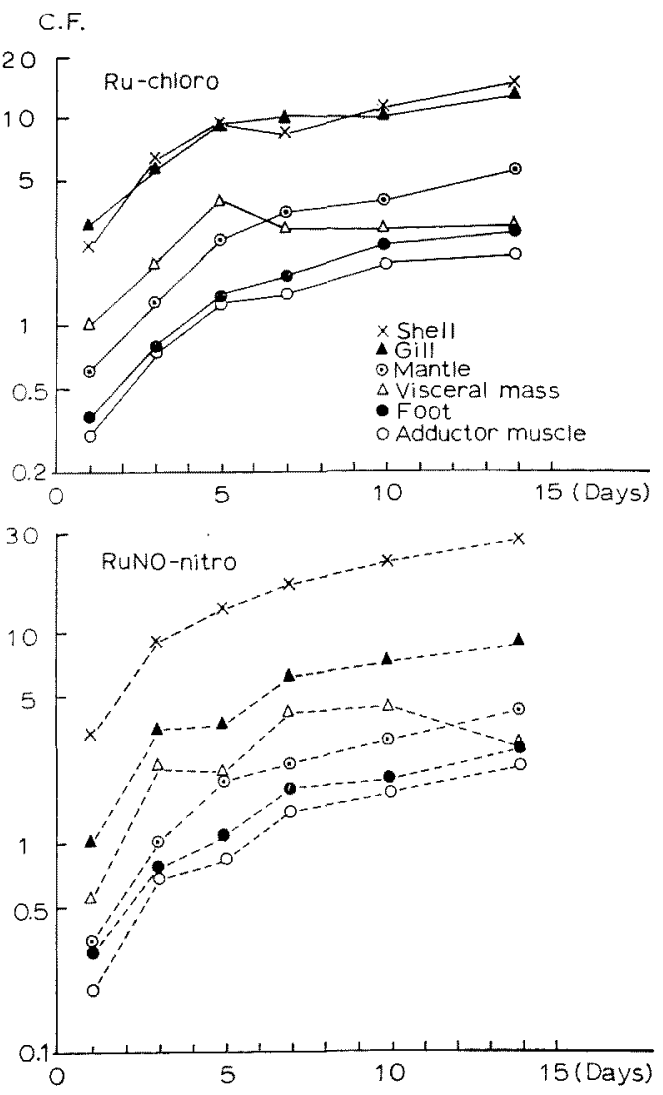

Fig. 2. Uptake of ${ }^{105} \mathrm{Ru}$ by short-necked clam, Tapes japonica, from sea water with sandy mud. 
reached apparent equilibrium condition in 2 weeks after the commencement of the experiment. It was found that the concentration of ${ }^{106} \mathrm{Ru}$ in the soft tissues showed generally similar features among these experimental groups and became lower in the order; gill, mantle, visceral mass, foot and adductor muscle.

The average concentration factors for each tissue at the end of the experimental period are shown in Table 1. Somewhat higher uptake of Ru-chloro than RuNO-nitro in some of the soft tissues was recognized especially for the group reared in sea water with sandy mud. On the contrary, radioactivity of shell was higher in RuNO-nitro group than $\mathrm{Ru}$-chloro. As regards the different rearing condition, most of the soft tissues appeared to have a little higher concentration in the group reared in sea water with sandy mud. This tendency is most conspicuous for visceral mass although difference due to chemical form was not found in this tissue. This may be due to the possible intake of radioactive sandy particle during filtration by clams in case of rearing in sea water with sandy mud. More remarkable difference is recognized in the level of shells. Concentration of ${ }^{106} \mathrm{Ru}$ in the shell reared in water with sandy mud was several times lower than that reared in sea water alone.

Table 1. Concentration factors for ${ }^{106} \mathrm{Ru}$ in short-necked clam, Tapes japonica. Each value indicates the average concentration factor of three specimens obtained at the end of the experiment.

\begin{tabular}{|c|c|c|c|c|}
\hline Organ & Ru-chloro & RuNO-nitro & Ru-chloro & RuNO-nitro \\
\hline Adductor muscle & 2.4 & 2.3 & 8.2 & 3.1 \\
\hline Foot & 2.9 & 2.8 & 9.8 & 4.0 \\
\hline Mantle & 5.6 & 4.2 & 17.4 & 4.9 \\
\hline Gill & 12.8 & 8.8 & 20.4 & 10.6 \\
\hline Visceral mass & 3.0 & 2.8 & 14.4 & 15.6 \\
\hline Shell & 14.9 & 28.0 & 2.8 & 5.1 \\
\hline Rearing condition & \multicolumn{2}{|c|}{ Sea water } & \multicolumn{2}{|c|}{ Sea water with sandy mud } \\
\hline
\end{tabular}

Therefore, when the activity of whole clam was divided into soft part and shell, the relative amount of activity contained in these tissues varied greatly being affected by the rearing condition as shown in Fig. 3. Much less containation of clam shell which was reared in sea water with sandy mud than in sea water alone may indicate that the relatively more adsorbable fraction of the nuclides in sea water was taken up by sandy mud resulting in less adsorption to clam shell. On the average $92 \%$ of the total activity (soft part plus shell) was contained in the shell and $8 \%$ in the soft part in the clam reared in sea water alone, while in the case of sea water with sandy mud, $44 \%$ of the nuclide was present in the shell and $56 \%$ in the soft part. These values obtained from the rearing in sea water 
were consistent well with the result obtained from the tracer experiment by Jones ${ }^{27}$ using a mussel, Mytilus edulis.
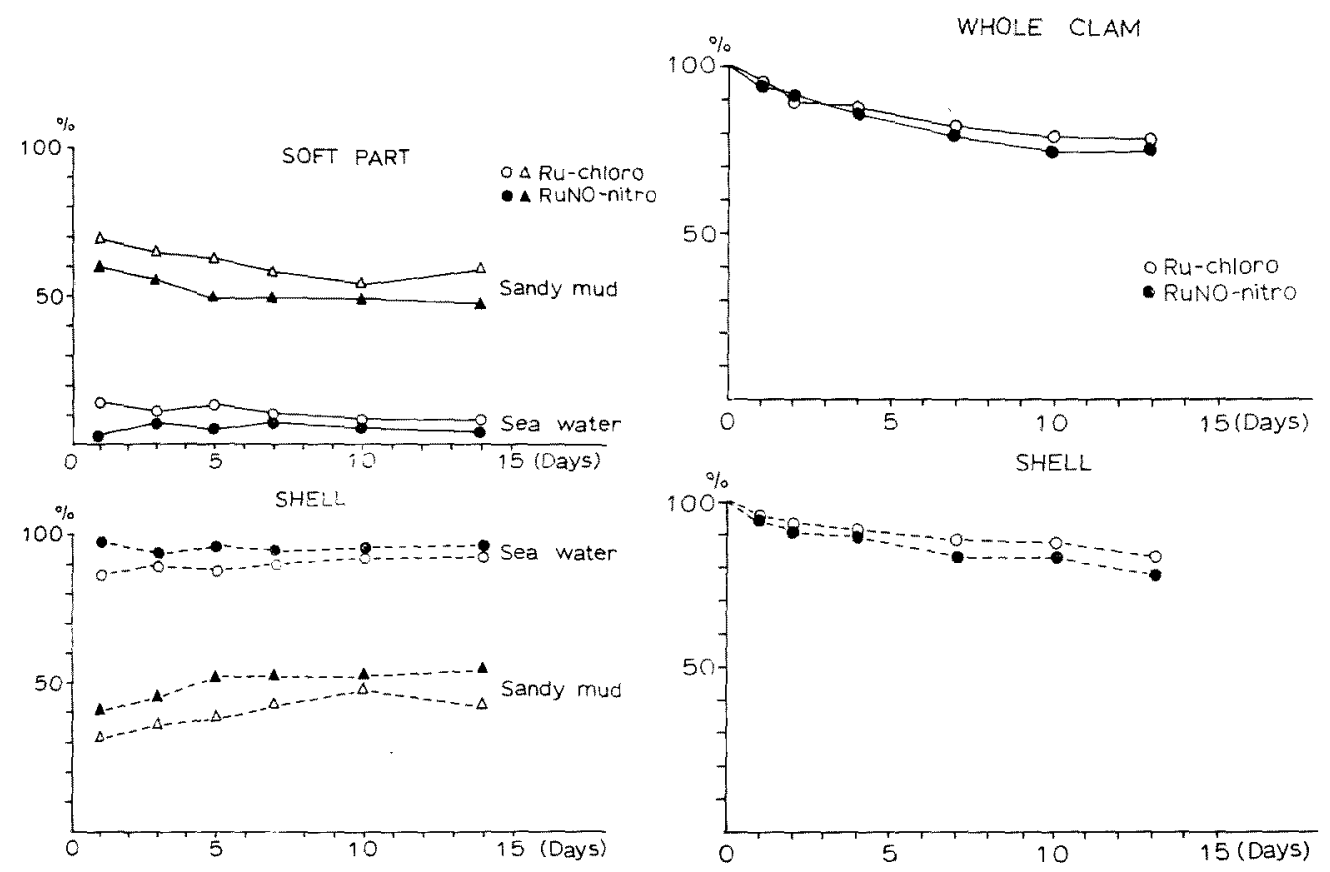

Fig. 3. Percentage distribution of ${ }^{106} \mathrm{Ru}$ in soft part and shell of short-necked clam, Tapes japonica.

Fig. 4. Retention of ${ }^{106} \mathrm{Ru}$ accumulated by whole clam and shell following return to non-radioactive sea water.

The retention of accumulated ${ }^{106} \mathrm{Ru}$ by whole clam was studied using some of the individuals which were used for the uptake experiment. It was found that the loss of the accumulated ${ }^{106} \mathrm{Ru}$ by the whole clam which was reared in the sea water with sandy mud was approximately $20 \%$ of the initial activity 13 days after returning to non-radioactive sea water, and the elimination pattern appeared to be identical in both chemical forms (Fig. 4). The loss of the activity from the contaminated shells without soft part in nonradioactive sea water was observed similar as that of the whole clam.

It has been well known that the shell of marine bivalve concentrates ${ }^{106} \mathrm{Ru}$ to a greater degree than the soft tissue. However, it was not ascertained whether it was transferred via its metabolic processes. In this respect, ${ }^{106} \mathrm{Ru}$ solution in three chemical forms, i.e., Ru-chloro, RuNO-chloro and RuNO-nitro was injected into the visceral mass of the clam. Substantial amount of injected ${ }^{108} \mathrm{Ru}$ was retained as shown in Fig. 5. The distribution of ${ }^{100} \mathrm{Ru}$ in the clam 7 days after injection is shown in the same figure. The transfer of the nuclide through the visceral mass into the shell was negligibly small in all three groups of clam when compared with the amount in the remaining part other than visceral mass. On the other hand, it was found that about $90 \%$ of the total activity of 

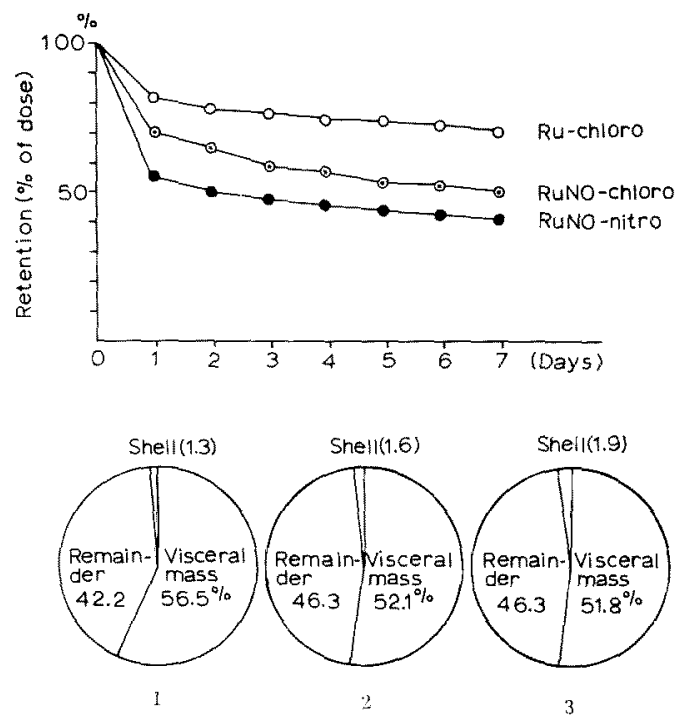

Fig. 5. Whole body retention of ${ }^{106} \mathrm{Ru}$ injected into the visceral mass of short-necked clam, Tapes japonica, and the tissue distribution of ${ }^{106} \mathrm{Ru} 7$ days after injection.

The number below circular graphs indicates the chemical form of ${ }^{106} \mathrm{Ru}$.

1. Ru-chloro, 2. RuNO-chloro, 3. RuNO-nitro. the contaminated shell of the uptake experiment was removed by immersion in dilute hydrochloric acid $(1 \mathrm{~N})$ and $70 \%$ was lost by immersion in $5 \%$ solution of potassium hydroxide or by polishing with neutral detergent. Considering these findings, it is assumed that the uptake of ${ }^{106} \mathrm{Ru}$ by shell is related to surface phenomenon.

Wilson $^{8 \text { ) }}$ reported that the effluent discharged to coastal sea from the Windscale Works contained radio-ruthenium both in solution and in the form of a co-precipitated with ferric hydroxide, and the ruthenium co-precipitated with ferric hydroxide became highly resistant to acid after ageing. Accordingly, he assumed that ruthenum in this form was not a serious source of contamination to the tissues of marine organisms. Jones ${ }^{2}$ had already recognized that the addition of ferric ions to the sea water containing nitrosyl ruthenium-106 resulted in an insoluble complex between the iron and the ruthenium.

In connection with the above-mentioned findings, the influence of $\mathrm{Fe}$ on the uptake of ${ }^{106} \mathrm{Ru}$ by the clam was investigated. In the present experiment, the uptake of ${ }^{108} \mathrm{Ru}$ by the organ of the clam was examined by rearing for twelve days in the sea water containing ${ }^{100} \mathrm{Ru}$ in $\mathrm{RuNO}$-nitrato form to which various concentrations $(0.1-10 \mathrm{mg} \mathrm{Fe} /$ liter) of ferric chloride were added. As shown in Fig. 6, uptake of ${ }^{106} \mathrm{Ru}$ by various organs of the Fe-added groups was somewhat less than that of the control group. This tendency was more recognizable in 1 and $10 \mathrm{mg} F$ groups than $0.1 \mathrm{mg}$ Fe group.

A peculiar feature was seen in case of visceral mass which showed a little higher value during the intial period followed by a gradual decrease for 1 and $10 \mathrm{mg} F e$ groups. This may due to the ingestion of particulate ferric hydroxide with ${ }^{106} \mathrm{Ru}$ which may not be absorbed and lost fairly rapidly.

It is well known that EDTA (ethylene diaminetetra-acetic acid) is one of the powerful chelating agent. In order to investigate the influence of chelating agent on the accumulation and elimination of radioactive substances by aquatic organisms, this compound has been frequently utilized by many investigators in the past.

Regarding the effect of EDTA on the uptake of ${ }^{106} \mathrm{Ru}$ by aquatic organisms, Tsuruga ${ }^{3)}$ 


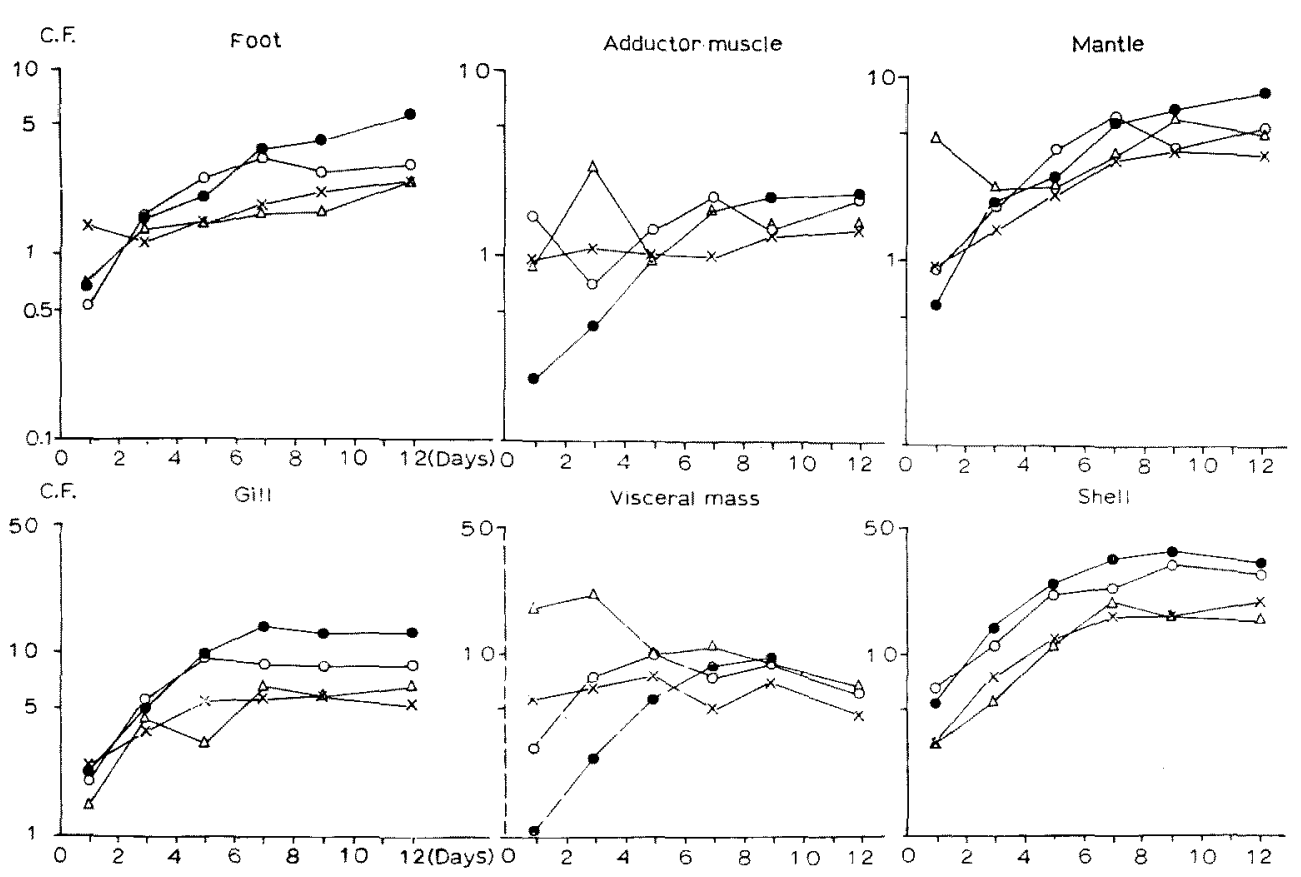

Fig. 6. Effect of $\mathrm{Fe}$ on the uptake of ${ }^{106} \mathrm{Ru}$ (RuNO-nitrato) by organs of short-necked clam, Tapes japonica.

Each mark represents the concentration of $\mathrm{Fe}$ in sea water.

$\bigcirc$; non-added, $0.1 \mathrm{mg} / l, x ; 1 \mathrm{mg} / l, \triangle ; 10 \mathrm{mg} / l$.

observed by the tracer experiments using a red algae, Porphyra tenera, that the uptake of radio-ruthenium from the medium, to which disodium EDTA was added, was a little less than those from the medium to which EDTA was not added. On the other hand, in experiments with fresh water organisms Getsova et al. ${ }^{9}$ found that EDTA caused relatively slight depression in the accumulation coefficient of ruthenium-106 for the leech, Herpobdella, but a marked depression for the mosquitoe larva, Culex pipiens.

In order to obtain this kind of information regarding the effect of EDTA on ${ }^{106} \mathrm{Ru}$ uptake by marine bivalve, the clams were reared for five days in the sea water to which ${ }^{106} \mathrm{Ru}$ in $\mathrm{RuNO}$-nitrato form and EDTA $(0.1-10 \mathrm{mg} / l)$ were added previously. As shown in Fig. 7, it was found that the uptake of ${ }^{106} \mathrm{Ru}$ by the soft parts of the clams reared in the EDTA-added water was not significantly different from that of the control group. On the contrary, the uptake of ${ }^{106} \mathrm{Ru}$ by the shells was suppressed considerably in the groups reared in sea water with 1 and $10 \mathrm{mg} / l$ EDTA, whereas no significant effect was observed for $0.1 \mathrm{mg} / \mathrm{l}$ group.

\section{Summary}

The uptake of ${ }^{106} \mathrm{Ru}$ by short-necked clam, Tapes japonica, was investigated under different environmental conditions. 

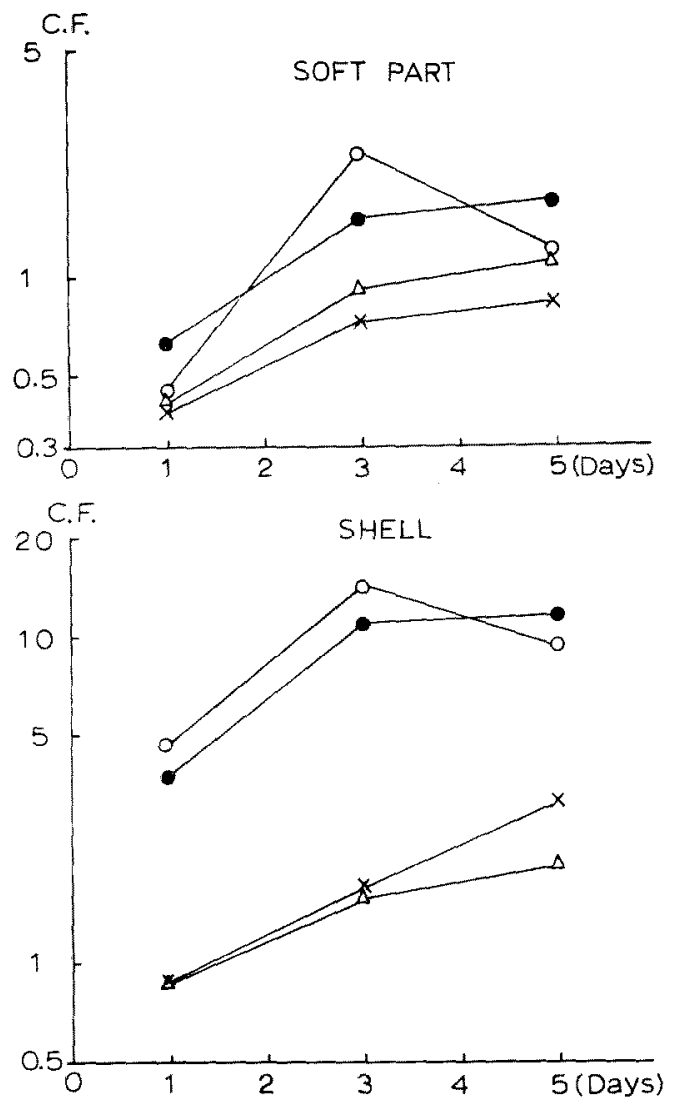

Fig. 7. Effect of EDTA on the uptake of ${ }^{106} \mathrm{Ru}$ (RuNO-nitrato) by soft part and shell of shortnecked clam, Tapes japonica.

Each mark represents the concentration of EDTA in sea water.

O; non-added, $\bullet ; 0.1 \mathrm{mg} / \mathrm{l}, \quad \times ; 1 \mathrm{mg} / \mathrm{l}, \Delta$; $10 \mathrm{mg} / l$.
It was found that the concentration of ${ }^{106} \mathrm{Ru}$ by the organ of the clam from sea water showed decreasing tendency in the order; shell, gill, mantle, visceral mass, foot and adductor muscle.

The effects of the chemical form, sandy mud, Fe and EDTA were found to be more conspicuous for the shell than for the soft tissue.

The authors are greatly indebted to Mr. K. Watari, Division of Chemistry, for supplying various ruthenium compounds and to Mrs. N. Takata and Mr. I. Suyama, of our Division for their technical assistance. Co-operation of the Chiba Prefectural Inner Bay Fisheries Experimental Station is also appreciated.

\section{References}

1) K. Kimura and R. ICHIKAWA: This Bull., 35, 434-440 (1969).

2) R. F. JONES: Limnol, Oceanogr., 5, 312325 (1960).

3) H. Tsuruga: This Bull, 29, 303-306 (1963).

4) Y. Hiyama and J. M. KahN: Rec. of Oceanogr. Works in Japan, 7, 79-106 (1964).

5) S. KeČKEŠ, Z. PuČar and L. MARAZović: In Radioecological Concentration Processes, Proceedings of an International Symposium held in Stockholm 993-994, Pergamon Press (1967).

6) S. Ké̌KEšs, Z. PứcAR and L. MARAZoví́: Int. J. Oceanol. and Limnol., 1, 246-253 (1967).

7) K. IWashima and K. Watari: Bull. Inst. Publ. Health, 18, $72-76$ (1970).

8) P. D. WILson: U.K.A.E.A., PG Report 819 (W), 1-8 (1968).

9) A. B. Getsova, E. A. Trmofeeva-Resovskaya and N. V. Timofeev-ResovskiI: Doklady Akad. Nauk SSSR 130, 440-442 (1960). 